\title{
Weaponization of the Land and Property Rights System in the Syrian Civil War: Facilitating Restitution?
}

Unruh JD (2016) Weaponization of the Land and Property Rights System in the Syrian Civil War: Facilitating Restitution? Journal of Intervention and Statebuilding. Published online

http://www.tandfonline.com/doi/abs/10.1080/17502977.2016.1158527

Author's prepublication version.

Keywords: Middle East, Syria, land tenure, post-war, restitution, evidence, mass claims, refugees.

\begin{abstract}
The Syrian civil war has seen the weaponization of its land and property rights system by the primary combatant groups in the country. The government is the most robust in its use of the tenure system to locate, target, destroy, confiscate, cleanse, and gain revenue by way of the institutions and attributes comprising the system. Based on fieldwork with Syrian refugees in Lebanon, Jordan, and Turkey, this article describes seven ways the Syrian government is currently using the land and property rights system in its military-on-civilian engagements. While the objective of such use is presumably to permanently prevail over opposition civilian constituencies, the article describes how this actually creates evidence usable for effective restitution of lands and properties subsequent to the war.
\end{abstract}

\section{Introduction}

The ongoing civil war in Syria has emerged as a laboratory of new weapons used by the various sides in the conflict. While a number of these are purely kinetic--involving both crude and innovative forms of firepower, executions, troop movements and strategies--others take advantage of society-based structures and institutions which facilitate targeting specific constituencies within the civilian population and then become attached to kinetic objectives. Statutory land and property rights systems are particularly vulnerable to being used in this way, with significant effect and lasting repercussions. While the Syrian government is not the first to use aspects of land and property rights systems in the pursuit of military objectives, it is the most current, egregious and sophisticated. This paper describes how the statutory land and property rights system has become an important weapon in the Syrian conflict with a number of uses, but with the ultimate counterinsurgency strategic objective of spatially and permanently prevailing over the insurgency and its civilian constituencies. Permanently ridding certain landscapes of opposition supporters and replacing these with pro-regime inhabitants is just as important to the overall objective of 'prevailing' as is military victory over insurgent combatants for the Syrian government.

This paper examines the use of institutions and attributes ${ }^{i}$ of the Syrian statutory housing, land and property (HLP) rights system in the conduct of the war. Different from fighting over land, or land rights being a cause of a conflict, this article describes the use of the statutory tenure system in or- 
der to: 1) target and destroy HLP records and administrative infrastructure; 2) locate and target anti-regime people and places; 3) target for destruction the HLP belonging to opposition constituencies; 4) confiscate, reallocate, and transact HLP and issue false documentation; 5) confiscate HLP documents at checkpoints; 6) derive significant revenue for the war effort; and 7) use state laws to evict and gain possession of HLP. However while use of a weaponized HLP system might seem to produce the near-term success and longer-term permanence for these seven military-oncivilian objectives, upon further examination the prospects dim. This paper argues that this weaponization inadvertently creates opportunities for: 1) countering some of the uses of HLP rights systems as weapons; 2) mitigating the ultimate impacts; and 3) moving against the presumed permanence of intended outcomes.

Subsequent to a description of methods, the paper provides a brief overview of sectarian politics and conflict constituencies, and then reviews current understandings of HLP rights systems used as weapons in armed conflict. A brief background to the Syrian conflict in an HLP context is then presented; followed by a description of the specific uses of HLP institutions and attributes in the conduct of the war. The paper then examines the repercussions and prospects for mitigation and countermeasures. A conclusions section then links the topic to the relevant theory.

\section{Methods}

Fieldwork was conducted in Lebanon, Jordan and Turkey in 2014 and 2015 and included individual, household and group interviews totaling 142 people. These were primarily Syrian refugees (residing outside of camps), and included men and women of different ages and from different socio-economic, rural - urban and professional backgrounds. The refugees varied in their relationship to their HLP in Syria, and included owners and renters of farms, houses and apartments; squatters and other inhabitants of informal urban areas; and members of groups attached to tribal land. The professional backgrounds of the refugees ranged from farmers, housewives, university students, teachers and journalists, to rural and urban wage laborers, and those working in real estate, law, architecture and business; as well as soldiers who had departed from the Syrian military. It is acknowledged that the refugees interviewed have a certain perspective of the regime. Thus some caution is warranted with regard to the refugees relaying objective truths. The intent is that this is mitigated to a degree by the non-refugee sources of information described below.

Apart from the refugees, journalists, teachers, land and property cadaster specialists and academics from Syria, Turkey, Iraq, Egypt, Algeria, Tunisia, and Lebanon who had experience working in Syria and the region were also interviewed. In addition, discussions were held with NGOs that included refugee assistance organizations, women's associations, and organizations that operated schools for Syrian refugee children. A review of the academic and grey literature was conducted on topics relevant to the use of HLP rights systems as weapons of war, HLP in war-affected contexts, the history of land and property rights in Syria, the conduct of the war, relevant Syrian laws, and refugee flows from the country.

\section{Sectarian politics and conflict constituencies: background}

Syrian Sects and the initial conflict

Syria's population of approximately 19 million are comprised of Sunni Arabs, who make up 65 percent of the national population; Alawites which constitute 12 percent; Christians who make up 10 percent; and Kurds and Druze forming nine and three percent respectively. The Bedouin, Is- 
mailis, Turcomans, Circassians, and Assyrians comprise the remaining one percent of the population (Kaplan, 2016).

The anti-government uprising in Syria, which began in March 2011 is largely thought to be advanced by the Sunnis, with some support from other groups (BBC, 2011). The Alawites are perhaps the most powerful sect in Syria due to their connection to President Assad who, like many members of the government and security services is from the Alawi community. Christians are distributed throughout the country, with large populations in Latakia, Homs, and Damascus. Prior to the conflict Christians enjoyed considerable religious tolerance and largely abstained from the initial protests against the government; with some leaders even addressing pro-government rallies. The Kurdish population is concentrated in the north and northeast of the country, particularly in Hasaka province (BBC, 2011). The Kurds in Syria have been denied basic political, social and cultural rights, and many have been officially stateless since Syria changed its nationality laws in the 1960s. At the onset of the current conflict however the government sought to allow citizenship for

Kurds, in an attempt to win their alliance. Nevertheless, there is significant representation of Kurds within the opposition groups, even though at the outset of the conflict they were divided over whether to back the government in the hopes of improved status, or back the opposition (BBC, 2011). The Druze reside primarily in southern Syria and their support was sought by both sides in the current conflict (BBC, 2011). The Syrian war has been described by others examining how it began (Hinnebusch and Zintl 2015), the response of the Assad regime to the unrest and the rebellion (Wieland, 2013), how the war further developed (Kilo, 2011), and the international response (Svoboda and Pantuliano 2015).

\section{The role of constituencies in the conflict}

While other studies highlight the role of sectarian division in the Syrian conflict, this analysis takes 'constituencies' to be more useful when looking at participation in varies ways and degrees in the conduct of the conflict. In this context constituencies are defined following Unruh and Abdul-Jalil (2014) as the immediate non-combat civilian support base for the armed movements, providing them with legitimacy, shelter, materiel and recruits. In this regard constituencies are the primary participants in narrative formation and development, as well as the primary recipients of benefits from combatants. Constituencies are smaller groups than the total population of any given sect, sympathizers or supporters, and can find themselves obligated to armed factions (including the state military). One of their primary characteristics is that they believe they have suffered or stand to suffer significantly at the hands of opposing factions and their constituencies--including loss of lives, livelihoods, land, property, and economic and political standing and opportunity (Unruh and Abdul-Jalil, 2014). Thus for any given sect involved in the conflict, the total population can be divided into three parts--combatants, constituencies, and the larger population that is more distant from day to day participation in the conflict. A focus on constituencies allows a more nuanced analysis of the war than assuming uniform alliance and participation of the entire population of any particular sect or group with the government or opposition.

For example, Alawites are not a homogenous population when it comes to their perspective on the regime and the conflict. The chairman of the Syrian National Council (opposition) noted that the Assad regime, "treated the Alawites the worst and those from the Alawite community that benefited from this regime make [up] only a tiny percentage" (BBC, 2011:2). At the same time the regime is able to draw certain minority communities closer to it (Reese 2013). For example members of 
the Druze have been recruited to form pro-regime militia to help the regular Syrian army (BBC, 2011). Likewise some Christians have held senior positions in government, and broader Christian participation in the conflict has ranged from abstaining, to support of the regime, to encouraging dialogue (BBC, 2011). As well, members of the Ismaili sect in Salamia, a city near Hama, have participated in both pro- and anti-government demonstrations (BBC, 2011). As well the Kurdish held areas that the regime withdrew from in July 2012 have pushed for autonomy and in so doing have clashed with both the Arab opposition and the regime (Caves, 2012). In addition there are Iranian civilians and military elements that are in the country and allied with the regime.

Within the opposition, various constituencies have formed that do not include all members of a sect. For example donors from Saudi Arabia and the Gulf support the conservative, jihadist and Salafist elements within the opposition (O'Bagy, 2013). At the same time those affected by the use of the statutory HLP system as a weapon include others outside of the primary Syrian sects. Refugees from Iran, Sudan, Palestine, Somalia, Iraq, and Afghanistan that have been resident in Syria for decades have also lost HLP and have now fled.

The Assad regime's relationship with the various tribes is likewise not straightforward, nor does it fall out necessarily along sectarian lines. Dukhan (2014) found that of the 22 tribes occupying the Al-Badia (Syrian steppe) region--covering 55 percent of the country and constituting 15 percent of the national population (Chatty, 2013)--four are pro-regime, eight are allied with the opposition, six are split, and four are silent or neutral on their alliance.

Thus while the widening conflict is often cast in sectarian tones, the core conflict in Syria is over control of the state, and in this regard the framework is not a purely sectarian one (Reese, 2013). As noted above the point of using HLP attributes as a targeting mechanism is to target specific constituencies within the civilian population, as opposed to the entire civilian Sunni population.

\section{Land and property rights systems in war-affected contexts}

While the fate of statutory HLP institutions and attributes during armed conflict is variable, primarily it comprises the dissolution of institutions; the scattering of personnel and equipment; and the destruction of buildings, databases and documentation. It also includes the capture of documents and resources for the personal gain of combatants and their backers, or to cover past abuses.

While coerced, forced, distressed, fraudulent and bad faith land and property transactions are fairly common in war-torn settings (Unruh and Williams, 2014), such processes more often reflect the activities of opportunists in pursuit of personal gain, as opposed to a purposeful military strategy. The Bosnian war however was known for its use of statutory HLP laws and institutions in order to facilitate ethnic cleansing as part of a war strategy (Toal and Dahlman, 2011). But apart from the Bosnia case the literature relevant to the purposeful use of HLP rights systems as weapons in armed conflict is scant. The extraction of high value natural resources to derive revenue streams to fuel one side or another in armed conflict (Lujala and Rustad, 2012) could be viewed as a weapon, but generally such scenarios involve capture of the valuable, easily movable resources themselves-diamonds, gold, timber--and not HLP or use of a property rights system.

Batson (2007) describes how a statutory land and property rights system can be used for intelligence purposes, focusing his work on Afghanistan. Such HLP intelligence can be used to, "uncover 
heretofore hidden familial, financial, and organizational ties of non-state actors" (Batson, 2007: 42). Likewise Demarest (2007) notes that use of 'property intelligence' can be important for counter-terrorism and counter-narcotics efforts and as such it is useful to the intelligence community. Finally, Bryan and Wood (2015) describe how certain kinds of mapping can be 'weaponized' in attempts to gain control over people and territory in peace-time. A look at the Syria case is instructive because: 1) the relevant technology (including hand-held devices and social media) is now well beyond what was present in the Bosnian war; and 2) there is a need to broaden our understanding regarding how an HLP system can become weaponized, in order to examine possible approaches for de-weaponization, mitigation, restitution and countermeasures.

\section{HLP in Syria - Background}

Although officially land and property in Syria is comprised of two categories, private land (38 percent) and state land (62 percent), in reality the tenure systems of the country comprise a range of Islamic, tribal, customary, informal, and statutory arrangements and hybridizations (HLP, 2013). While HLP registries existed in all 14 Governates prior to the war, these only covered HLP transacted within the statutory system, and there was no central register.

Just over half of the country's 22.5 million inhabitants lived in urban or peri-urban areas prior to the onset of the conflict, and approximately one-third of the urban population (3.4 million people) lived in informal settlements; which while lacking official recognition and registration, had services and were well laid out (HLP, 2013). In Damascus approximately 40 percent of the population lived in informal settlements, while in Aleppo almost half of the population lived in such settlements. Most lower income urban neighborhoods had informal structures for decision making, usually established around processes of informal land and property distribution and development. These were usually guided by local leaders and other unofficial actors who facilitated property transactions (HLP, 2013).

In rural areas customary tenure systems prevailed (HLP, 2013). The refugees note that rural land is acquired in Syria largely by a form of prescription, with purchase, renting and sharecropping common and usually occurring through the extended family or lineage (also Al Zoughbi, 2004). Such an approach to land acquisition over the course of history, along with marriage and inheritance, meant that certain family and lineage names came to be attached to specific areas. While the size of such areas varied, this aspect of land tenure in Syria has now come to be critically important in the war (elaborated below). An important context for rural Syria is that the country's worst drought lasted from 2006 to 2011 and covered approximately 60 percent of the country. The drought saw approximately 75 percent of agriculturally-based households suffer total or near total crop failure, with attendant social and economic problems (HLP, 2013). An aspect of rural land tenure in prewar Syria that created great animosity, was the takeover of lands by elite private interests via designation of areas as military zones. Such designations were not subject to civil land and property laws and resulted in numerous evictions without compensation.

Estimates at the time of writing put the total number of dislocated civilians at 11.6 million, approximately half of the civilian population (UNHCR, 2015). While wealthier refugees may have had the opportunity to plan their departure and transfer money, documents, and some possessions out of the country, for the less well off (most) their departure was much more immediate and chaotic. In addition a proportion of refugees did not possess statutory documents attesting to their HLP 
rights in the first place--although they may have possessed informal documents. These include many from the rural areas who relied on customary and tribal tenure systems, inhabitants of the large informal peri-urban settlement areas, and a variety of non-citizen refugees (HLP, 2013).

\section{Weaponizing the HLP System}

The utility of the HLP rights system to the conduct of the war is well recognized by all parties to the conflict. While the Syrian government seeks primary military and demographic advantage in pursuit of this utility, pro-government constituencies are able (and encouraged) to pursue business opportunities connected to this advantage, as do certain outside backers of the government. Refugees and IDPs feel the impact of the weapon the most, as they are targeted, dislocated, and attacked, while presumably losing the ability to reclaim their HLP. Those not yet dislocated who are either neutral or supporters of the rebels, are also impacted as they withdraw from engaging the HLP system for fear of being targeted and losing their HLP or worse. This group is also unable now to go to local HLP offices to request documents and services. Rebel combatants must contend with the strategic disadvantage of the government's use of the HLP rights system, as do ISIL forces; although both have their own approaches to using HLP to wartime and postwar advantage. For example new recruits (often Syrian refugees in exile) are offered houses as part of a compensation package for joining the rebel movement (Khraiche and Syeed 2015). This section describes seven uses of the HLP rights system by the government in the war, as described by Syrian refugees and others during the fieldwork, and supported by the existing literature. While these uses will have variations across the country, obtaining information on such variations was beyond the scope of the fieldwork and this paper, whose intention is instead to describe the types of weaponization, as opposed to variations within each type.

\section{Targeted destruction of HLP records and infrastructure}

The purposeful destruction of HLP administration buildings and offices in anti-regime areas along with the records they contain, is of primary utility to government efforts at spatially prevailing over the opposition--both combatants and civilians. ${ }^{\text {ii }}$ Destruction of records that could attest to the ownership of HLP in anti-regime areas has two effects. The first is to prevent claiming or reclaiming HLP assets by the original owners (also Chulov and Mahmood 2013). This includes preventing people from going to HLP offices to obtain documentation so that they can depart with them, while also serving as a public message that important evidence for HLP claims is now destroyed. The second effect is that it allows occupation or transfer of HLP to pro-regime individuals, commercial interests and government units. Those spoken to during the fieldwork indicated that while in most cases the HLP records were clearly targeted for destruction, ${ }^{\text {iii }}$ in other cases the government took the electronic media containing records and then destroyed the paper documents along with the buildings. The purposeful destruction of paper HLP records at different levels of government has had a significant overall effect because electronic archiving of these records in Syria (allowing copies to be stored in multiple places) only started the year before the uprising in 2011, and with new records only. Thus the job of equipping all HLP offices in the country with the means and training to produce electronic records was not complete and not in place country-wide when the war started. The work then of making electronic archives of older HLP documents had likely not begun at all. 
Destruction of HLP administrative offices is especially common in the opposition areas of Homs and Damascus. In the case of Homs the HLP records were burnt when the land registration department building was destroyed. The purposeful targeting of the building was notable because it was the only structure burned in the most secure part of the city. Local residents indicated that they felt they were no longer able to enforce their claims to their lands and properties (Chulov and Mahmood 2013). Homs is thought to be crucial to any plans for a future Alawsite state in the event the government loses the rest of the country (Salameh 2015); meaning that the 'weapon' use of HLP office and documentation destruction is important to objectives involving demographic change.

\section{Locating and targeting anti-regime people and places}

An important HLP weapon in the conflict is for the government to explicitly use registers and other (including non-statutory) records of ownership, rental, leasing, and inheritance to detect locales inhabited by certain lineage names thought to be supporting the opposition. Because HLP registers and other documents precisely attach names to location, knowing which lineage names support the opposition can lead to their location; and conversely knowing where the opposition areas are, can lead to the lineage names inhabiting them. Thus HLP registries and other documents facilitate targeting by government forces. ${ }^{\text {iv }}$ The use of registries and documents in this way serves several objectives. One of these involves the dislocation or eradication of as many people as possible in the area of concern so that the population cannot reclaim their HLP later. This is especially the case for valuable lands and properties, or for lineages or areas thought to be particularly supportive of or participating in the opposition. This then subsequently facilitates either placing pro-government constituencies on these lands or selling them to domestic or international interests in the wartime land and property market.

Use of the HLP system to target people and places also has secondary consequences that enhances the 'weapon effect'. Once it becomes known among the general population that the government is using the system to locate people and properties, it compels still more people to flee and leave behind their documents. And like the destruction of offices and records noted earlier, it acts as a strong deterrent to those who might attempt to go to government offices to obtain copies of their HLP documentation to take with them. As well it encourages people to abandon the statutory system for any rental, lease, sale, purchase and inheritance practices and procedures that were underway, and not engage it thereafter. The reluctance of the population who are either neutral or support the opposition to continue to take part in the statutory system, while the pro-regime population continues to use it, has the effect of deeply politicizing the HLP system.

\section{Targeting HLP for destruction}

The use of records for the direct targeting of certain residential areas, lands and properties for destruction, is specifically designed for the purpose of dislocation and making population return next to impossible (HIC-HLRN, 2015). The intent of this targeted destruction is made clear by the fact that just one year and a half into the war, over one-third of the real estate in the country had been destroyed by shelling. The largest proportion of this purposeful destruction is concentrated in the informal settlement areas around cities, where the poor of Damascus, Hama, Homs, Dar'a, Dayr alZur, Aleppo and other urban areas reside (HIC-HLRN, 2015). ${ }^{\vee}$ This particular tactic is not new to Syria. Under Hafaz al Assad, following the 1982 massacre in Hama and Homs, the government 
destroyed houses and built new ones on top of where the old ones stood, to be occupied by people allied with the regime (HIC-HLRN, 2015).

A number of refugees noted the purposeful destruction of large numbers of olive tree groves by government forces in order to frustrate any subsequent claims to the land based on claims to the trees. One estimate is that up to three million olive trees have been purposefully destroyed, because, as one refugee noted, "each tree has an owner" and hence is evidence for a land claim. Purposefully planted economic trees involving specific species are widely recognized in statutory and customary tenure systems around the world as robust evidence for land claims (e.g., Meinzen-Dick et al., 2002). And certainly destruction of olive trees in order to obliterate land rights is a known tactic in the Middle East (Braverman, 2009). The proportion of tree crops in small, medium and large landholdings in Syria according to one study of a primary agricultural area was 30, 60 and 85 percent respectively (Al Zoughbi, 2004), making such trees a primary form of evidence for claim, and as a result an important target.

\section{Confiscation, reallocation, transaction and false documentation}

In a process parallel to the destruction of the HLP belonging to opposition constituencies, the refugees and others spoken to were explicit in their understanding that the government was putting people allied with the regime into HLP that had been abandoned by those who fled, and was issuing falsified property documents to facilitate this. This form of spatial cleansing (along with processes noted earlier) seeks to transform the demographic structure of the country. The refugees note that this is both to facilitate the prosecution of the war, and importantly, to realize specific objectives in its aftermath (also Chulov and Mahmood 2013). The refugees report that Iranians comprise a significant proportion of the new inhabitants, and that they include businessmen and military personnel, as well as the relatively poor. The newcomers are not only given property documents but apparently citizenship papers as well. Syrian refugees in Turkey reported that along with the new inhabitants, street names have been changed. If true this would mean that HLP documents held by the previous inhabitants would contain now incorrect location information, making future efforts at reclaiming more difficult.

A particular issue in Damascus and its suburbs are the multi-residential buildings used by the urban poor. Such buildings and their inhabitants are often not officially registered and there is a good deal of informality and corruption with regard to occupation of these buildings. As a result, the government often does not know who resides in such buildings, and is now taking them over during the war, claiming that they are unregistered and so belong to government. This occurs particularly where people have fled and left such residences empty, thus indicating to government that they support the opposition. This also suggests to government which urban areas could be considered to be supportive of the opposition.

Apart from putting pro-regime constituencies in the HLP of those who fled, the Syrian government also encourages pro-regime civilians to, on their own initiative, take over HLP left vacant by dislocatees. ${ }^{\text {vi }}$ Such wartime acquisition of refugee and IDP properties is currently a widespread business opportunity involving subsequent sale, speculation, or holding for later use or transaction. There was ample evidence among the refugees interviewed that there is a wartime surge in transactions involving pro-regime individuals (particularly those with connections to government) engaged in selling refugee HLP. 
A related strategy is for the government to confiscate the HLP of famous people connected to, or assumed to be sympathetic to or supporting the opposition--well known actors, journalists, intellectuals, artists, etc.--and then making this widely known among the broader population. This was the case for Jay Abdo, a famous Syrian actor (Anthony, 2014). The refugees understand this to be a message that, if HLP confiscation can happen to well known individuals, then it can also easily happen to the ordinary person, thus encouraging abandonment of HLP and discouraging attempts at reclaiming.

\section{Checkpoints: confiscating HLP documents}

The use of HLP documents (including non-statutory documents) confiscated at checkpoints from those attempting to flee the country is presented here as a separate tool because of the immediacy of attaching people to locations they come from or own property in, given that both documents and people are present together with government personnel at the checkpoint. Examination of documents confiscated at checkpoints allows the government to ascertain the area in which those fleeing come from, the number and type of landholdings they own in the area, and the lineage and family name(s) attached to the holdings. With this information they are able determine if they were fleeing from an opposition area, and if this was the case they could be arrested or disappeared and their broader lineage and location of origin put at risk.

\section{Enabling the financing of the war}

An important government use of refugee HLP is the transaction of such assets in order to help finance the war. The refugees indicated that this occurs in two broad approaches. The first approach involves the Syrian security services confiscating and selling lands and properties belonging to people connected to the opposition. A variation of this approach involves multi-residential buildings known to belong to supporters of the opposition but still inhabited by tenants. In this case the security services compel the tenants to sign new contracts obligating them to pay a monthly rent to the government. While reported by the refugees to occur in Latakia and nearby suburbs, the same approach is also evident elsewhere (MEM, 2015).

The second approach involves the confiscation of large areas that were inhabited informally, and are now largely vacated as part of the targeted dislocation and demographic change plans in and around cities such as Damascus and Homs. There are already plans (and associated financial arrangements) for companies from the Gulf states and Europe to get large contracts for the redesign and rebuilding of these areas; particularly in what will become valuable urban and peri-urban areas, fertile and well watered rural areas, potential industrial zones and residential areas. For this to be realized however HLP rights for these areas would need to be largely free of counterclaims, especially the mass claims common after wars, and be easily transferred to the new HLP rights holders. In an attempt to do this the government takes advantage of the fact that in many of the poorer and informal areas HLP were not officially registered, ${ }^{\text {vii }}$ while in areas supporting the opposition HLP records have largely already been compromised, with most of these areas now substantially emptied of their occupants.

The international interest in lucrative rebuilding contracts is significant. In 2013, just two years after the uprising began, a conference was held in Europe on the topic of, 'Prospects and Opportunities for Postwar Growth in Lebanon and Syria' (Chakrani 2013). One estimate puts the cost of 
reconstruction efforts in Syria at between 65 to 100 billion USD if the war were to have ended in 2015. European countries are reportedly very interested in finding business for their construction companies, and are making their interests known and preparing for future opportunities (Chakrani 2013).

A separate set of reconstruction plans involves cooperation with Chinese, Russian and Iranian commercial interests. These plans depend on the government gaining control over opposition areas, and explicitly seeks confiscation of HLP in the unregistered informal areas that support the opposition (HIC-HLRN 2015). A specific case highlighted by a number of refugees is the purchase in 2012 (a year after the uprising began) of a large amount of land between the Damascus city center and the airport by a Qatari company in order to develop it. And reportedly there are several web pages with images of how the city of Homs would look once it is rebuilt after the war. ${ }^{\text {viii }}$ While the specific activities of any one company will no doubt change over time, the point here is that such commercial interests reveal an aspect of HLP weaponization.

\section{Use of state laws}

Prior to the war the Syrian state was well practiced in the use of laws to expropriate property, particularly from the Syrian Kurdish population (HIC-HLRN, 2011). Certainly the war has created a highly enabling environment for this tactic, which private individuals also take advantage of (Stigall, 2014). One interviewee noted that there has recently been a court finding that HLP abandoned during the war now belongs to government for it to dispose of as it wishes. And two years into the war the government issued Resolution No. 18905 in 2013, allowing it to confiscate numerous HLP in certain areas ostensibly in order to install electric power projects (SN, 2013). Only one year into the war in 2012, the president of the Damascus Governate had developed a tactic to 'replan' informal, unregistered areas, with the intent of making it extremely difficult for the original occupants to reclaim their HLP (HIC-HLRN, 2015).

While the Tourism Ministry has a pre-war law that allowed it to take over old buildings, including residences that were considered to be of historical value, the refugees interviewed noted that in the war period this law is used to conduct evictions on significant scale in order to take over and control whole areas. Another law being used is the outdated and much abused Expropriation Law. For many Syrians in the current crisis this law is a primary concern. Even before the war it was the source of significant discontent for a substantial percentage of the populace because it was widely used for the purpose of state and private takings (Abdallah, 2011).

\section{A postwar ungovernable housing, land and property scenario?}

Given the aggressive use of the statutory tenure system as a weapon of war against significant portions of the Syrian population, subsequent to the conflict the likelihood that the tenure system will be able to return to anything resembling its prewar form is extremely low. Two processes will drive an almost certainly ungovernable statutory HLP rights scenario after the war. First, the use of the tenure system as a weapon certainly destroys it for subsequent civilian use--with the destruction of lands and properties along with documents, administration buildings and equipment actually constituting the lesser part of the problem. The most important component of any tenure system is trust, which is also the most easily and quickly destroyed and the most difficult to recover (Murphy, 2003). Large segments of the Syrian population stopped participating in the statutory tenure system before they fled as it became known that the government was using the system to target 
those thought to be opponents along with their HLP. As a result, trust in the statutory property rights system has been driven into profound mistrust and suspicion. The majority of the population not explicitly connected to and benefiting (constituencies) from the Assad government will likely not again have trust in a statutory tenure system similar to what existed prior to the war. And a great many will likely not trust any statutory system by any new government given the now well known utility of such systems as weapons.

Thus in a scenario where the government wins the war, the lack of legitimacy of HLP institutions will mean they will not be engaged by the majority of the population, who will instead evade them and default to forms of more locally legitimate and accountable customary, Islamic or hybridized tenure systems that are not able to be accessed, controlled, or used by government. And this may include a significant reluctance to use even informal documentation. Stigall (2014) notes that such substate institution building is already underway in Syria by different movements. Tenure systems that are able to evade, resist and challenge the state exist in numerous countries around the world and can evolve quickly, invoking a variety of customary, indigenous, religious, and ideological forms of legitimacy (Cohen 1993). In Syria this will be encouraged by the ongoing presence of fraudulent and politically motivated practices, documents, use of institutions and laws, and claims by pro-government individuals and others who have ended up with HLP belonging to refugees and IDPs. In such a scenario, those who are aggrieved over HLP matters can be expected to act against the new occupants, institutions, and government personnel, and seek out or be drawn into a 'social service providing' aspect of certain armed groups who are willing to act on behalf of such grievances in order to grow their own constituencies (e.g., Stern 2010).

The second process is that as in any armed conflict, the use of a weapon system necessarily means that opposition forces will fight with the objective of destroying that system. This presents a significant problem in a recovery context as Stigall (2014:9) notes for Syria, where the rebels are, "locked in an intensely violent conflict with the Syrian state and, therefore, against many of the same institutions which will be needed to govern in the conflict's aftermath". Thus the statutory tenure system that existed prior to the war is currently being destroyed by both the government (through its use as a weapon) and the anti-regime rebels, supporters and others (by distrusting and disconnecting from it). This concurs with Stigall (2014:8) with regard to the Syrian war whereby the revolution constitutes, "a violent upheaval which eliminates existing institutions [and] extirpates the deep state".

\section{Prospects for recovery of HLP rights in postwar Syria}

\section{The civil code and Islamic law}

Given that reconstruction of the pre-war statutory tenure system is unlikely after the conflict, two features of broader Syrian HLP rights will likely emerge as strengths upon which postwar tenure systems may be built: 1) the high regard and respect that the majority of the populace places on the core Syrian civil code (Stigall 2014); and 2) the ongoing resiliency, functionality and widespread understanding of the customary-Islamic land rights mix among different groups in the country (Rae, 2002).

Stigall (2014) writes extensively and thoroughly about the potential utility of the Syrian Civil Code after the war, its deep historical role in the development of Syria, the respect for it by the Syrian population, and provisions within it that are potentially able to assist with population return in spite 
of extra-codal legislation being used to dislocate (Stigall 2014). In this regard Stigall (2014:42) notes that the Syrian Civil Code is a fundamental part of "a deep and well-rooted legal culture, the undergirding theories of which have annealed through centuries of legal development." In the current research this concurs with the refugees own opinions that it is not the core legal structure which is bad and needs replacement, but rather who operates them and how. Debs (2010) notes that Syrian property law retains much more Ottoman influence than the property laws of other countries in the region. Ottoman legal concepts still operable as part of the Syrian Civil Code are well able to handle a variety of evidence for claim, property recovery and restitution (Stigall 2014) quite apart from the operation of a centralized statutory property rights system and current Syrian government efforts at falsified documentation, ethnic and sectarian group membership, and political alliance.

In a customary-Islamic law context, there are a variety of constructs and legal devices that are highly useful in post-conflict contexts, and Sait (2013) and Sait and Lim (2006) comment very effectively about these.${ }^{\text {ix }}$ Customary law is fused with Islamic law in Syria, as it is throughout the Muslim world (Sait and Lim 2006). Sait (2013) further notes that such constructs have existed for centuries alongside and after conflicts and so are well adapted to facilitating post-conflict HLP recovery, and often in ways that evade the state. Stigall (2014) further notes that in the Syrian context the Civil Code draws significantly from components of Islamic law regarding property rights, and there are a variety of Islamic-based constructs in the Code that will be useful in a postwar context. Particularly noteworthy are the constructs that disfavor bad faith acquisitions, including acquisitions obtained by deception, force or through secret or ambiguous dealings; and other constructs which allow displaced persons to regain possession via reoccupation and other 'possessory actions'.

Post-war mass claims programs for HLP restitution are frequently conducted at the behest of the international community, with legitimacy and legal basis drawn from both domestic legalities and international law (Dans and Van Houtte, 2008). The two interconnected strengths in Syrian land and property law--the core Civil Code and the customary-Islamic mix--operating in local, decentralized contexts could provide the potential to constitute the foundation of a workable HLP rights system that can be supported by international mass claims law for the purpose of deriving a largescale restitution framework. One concern however with the loss and exploitation of so much documentary evidence over the course of the war, is that a significant obstacle to HLP restitution is thereby created. As it turns out however this lack of evidence is mitigated by the parallel production of war-time evidence useful for HLP restitution.

\section{The production and conservation of corrective evidence}

While kinetic weapons leave behind evidence of their use, such evidence cannot generally be used to correct their kinetic impact. Weaponized HLP institutions on the other hand, in their use, actually produce evidence usable for a corrective in terms of HLP restitution. This occurs in two processes that result in the production of two separate sets of evidence. In addition, a parallel process occurs with war-affected HLP institutions that safeguards still a third set of evidence. Thus while the use of the statutory HLP system as a weapon of war in Syria would appear useful to the government in the near-term, it is also inadvertently producing and protecting a significantly large quantity of evidence useful for facilitating redress, restitution and compensation. And importantly 
there is little that can be done at this point to destroy, suppress, or hide this evidence and its value as it continues to grow.

The first type of corrective evidence is produced via the institutional acts of using the HLP system as a weapon. Orders and communications going up and down the chain of command regarding locating, targeting, confiscating and destroying HLP are themselves evidence usable in restitution efforts. One example is the issuing of false or 'new' documents to those that come to occupy HLP vacated by those who fled. Such documents are unconnected (in statutory, customary or Islamic legal domains) to the historical sequence of transactions, transfers, and use (purchase, inheritance, rental, loaning, etc.). Even the physical existence of such new documents (along with the documentation involved in the ordering, manufacturing and implementation of their issuance) during war-time and pertaining to areas where people fled, are evidence of their falsity and hence prior ownership by others who were dislocated. The attributes of the new documents, corroborated by military activity in location $\mathrm{X}$ at time $\mathrm{Y}$, are evidence of false, bad faith, and illegal HLP takings--in other words evidence that 'cleansing' took place. Thus the organized takeover of HLP from the original occupants produces a broad complement of evidence of false occupation and ownership that can be used to support HLP claims of Syrian refugees. Even 'distress sales' or coerced or bad faith purchases produce evidence as to the nature of the transfer.

The priority would then be to obtain and use such evidence. However a similar process regarding war crimes is already underway in Syria. Currently, two separate teams of investigators are collecting a wide variety of evidence produced by the regime in its wartime activities that attest to war crimes (Simons 2014). This evidence--prison records, minutes of meetings, military orders, etc.--is being collected as government positions fall to rebel control, with its production due largely to a government, "mania for documentation that we haven't seen since the Khmer Rouge and the Nazis" (Simons 2014:A10). The collection of the documentation is intended to be used for the prosecution of criminal liability in any future war crimes trial. But the documentation is more than evidence of particular crimes. They also reveal, "the structure of command, control, and communication" (Simmons 2014:A10). In other words the collection and analysis effort reveals the functioning of institutions and organizations in the conduct of the war as well as particular incidents. As Simons (2014) notes, there are orders coming down the chain of command, reports going up, and reports on logistics and operations being produced in triplicate or more, and sent to different government departments in addition to the security and intelligence agencies. As of the end of 2014 an estimated half million pages of documents--tons of paper--have been removed from Syria in this effort, usually through Jordan or Turkey and on to the investigators' offices in Europe (Simons 2014).

The second type of evidence produced is largely corroborative. In this regard it is common practice in postwar mass claims and restitution programs to corroborate HLP claims with other events, data, and timelines. A wide variety of seemingly unrelated information can be used for this purpose (Dans and Van Houtte, 2008). In this technique, what is sought is corroboration in time and space that certain events took place, resulting in dislocation and loss of HLP. Contemporary conflicts produce immense quantities of event-related information that, unlike earlier civil wars, is now accessible on the internet--from news reports to cell phone photos and videos. Lynch et al. (2015) describe at length the different databases derived from social media and forms of analysis performed that are able to provide a great deal of insight into specific events, processes, locations, and 
constituencies that could be used to corroborate different forms of restitution claims. The majority of refugees spoken to during the fieldwork engage in social media and posses a wide variety of onthe-ground information about their HLP and specific war-time events in their home areas; and continue to receive such information from friends, neighboors, and relatives still in Syria. When asked if HLP-specific information could be requested from colleagues still in the country, the refugee response was almost universally 'yes.'

A third process involving still a separate evidence set occurs on its own in virtually all wars. A nearly pervasive feature of wartime is that a significant portion of HLP documentation is inevitably copied or taken from HLP offices as the war intensifies or moves to new areas. This is done by employees or former employees within government at different levels and locations as they depart their places of work when offices begin to cease functioning with the advance of the conflict (Unruh, 2014). This includes offices that are not yet threatened by the conflict, but whose personnel either believe they could be threatened at some future date, or that they may soon lose their employment or not get paid as the broader war progresses (Unruh, 2014). These personnel are in a unique position to know how valuable this documentation is, primarily as potential future negotiable assets in a variety of ways. But other actors know their value as well, such that documents and archives are frequently targeted and looted by other opportunists as the war intensifies. In aggregate this results in a series of 'mini-archives' hidden within and outside the country among a variable set of actors. While retrieving these after a war can be complicated, there are a number of feasible approaches (Unruh, 2014). For Syria, interviews with refugees indicate that significant quantities of such documents are in many instances now already outside the country.

Related to the production and conservation of HLP evidence is the issue of how to manage fraudulent HLP documents as evidence for claim. Fortunately the treatment of fraudulent documents subsequent to a war has an instructive history. The international community active in postwar scenarios can encourage and even insist on the application of certain legal decrees that freeze all transactions, or types of transactions in specific areas, retroactively. These can be applied to some or all HLP transactions in specific areas of a country and/or over certain periods of time when it was known that such 'bad faith' transactions or the issuing of fraudulent documentation took place (Williams, personal communication, 2009). A variation of this technique was used in postwar in Iraq, where forced, fraudulent, and illegal land and property transfers, or transfers suspected of being so, were frozen en-masse and not allowed to proceed by the Property Registration Department (Isser and Van der Auweraert, 2009). Bosnia (at the strong urging of the international community) also used a similar approach to nullify many war-related transactions and transfers of HLP; and such an approach could be tailored for use in a postwar Syria.

\section{Conclusion: A variant of warchitecture?}

In civil wars where opponents include portions of the civilian population, the weaponization of HLP institutions and their attributes has three broad purposes, 1) to assist in kinetic operations (locating, targeting, capture and destruction of specific peoples, HLP, records and the connections between these), 2) to prevail over civilian constituencies supporting the opposition through permanent demographic change, and 3) to assist in financing the war effort. Such uses can be seen to reside proximate to what Herscher (2008:42) terms 'warchitecture', whereby, "violence against architecture transforms, often fundamentally, the values, meanings, and identities of architecture". In this regard the status of a building as symbol and service is fundamentally altered subsequent to 
attack, damage or destruction, thereby transforming meanings, values and identities associated with the building and its symbolic and real use and service. While Herscher's work focused on the former Yugoslavia, it does resonate in the Syrian context in that the intent of the destruction of specific HLP and HLP administrative buildings is to engage in this change. The arc of reasoning for targeting Syrian HLP is similar to what Herscher describes for the war in the former Yugoslavia--from the initial labeling of the target (certain HLP as hotbeds of opposition) in order to legitimize destruction, to the transformation of meanings due to destruction (with architecture in this sense acquiring meaning only with its destruction), and then post-destruction plans for urban renewal to solidify the elimination of threat from and conquest over groups against whom war is waged (Herscher, 2008). But while Herscher's warchitecture seems to focus on the symbolic, political and cultural aspects of architecture in war, particularly with regard to the impact on people, in the context of HLP in the Syrian case, the effect, and in fact the objective, is to purposefully destroy the fundamental aspect of property rights, which is--social relations between people about property (Pipes, 1999). Thus the purposeful destruction of HLP administrative buildings and contents, along with other HLP assets would seem to expand the impact of warchitecture beyond what Herscher describes.

But Herscher's warchitecture theory also allows expansion of the utility of 'corrective evidence' noted above. Herscher asks critically important questions regarding this form of evidence. "Who inflicted destruction? What was destroyed? Why was it destroyed? These are the kind of questions that most often organize accounts of wartime destruction" (Herscher, 2013:38). The value of such questions to the production of evidence useful for prosecution and HLP restitution is explicit, "[a]n examination of destruction through the identities and intentions of its authors can certainly provide useful information" (Herscher, 2013:40). Relevant to Syria, Weizmann and Herscher (2011) note that in the Hague Tribunal for Kosovo, prosecutors attempted to elucidate the chain of command that delivered orders to ground forces for the destruction of mosques--thus revealing evidence of intentional destruction by specific actors.

Weizman and Herscher (2011) go on to elaborate the meaning of architecture as 'witness', and they describe 'forensic architecture' as providing evidence in law, such that the "framing of architecture as evidence, especially in a juridical context, adds new layers to architecture's identities, meanings, and functions" (Weizmann and Herscher, 2011:115). Further, descriptions of materials, surfaces and structures of buildings as holding clues regarding the event that led to their destruction, such that exposed building surfaces become 'sensors' that reveal 'dynamic microtopographies' (Weizmann and Herscher, 2011), add much to the potential of forensic archeology regarding the task in Syria. Similarly Wilson (2008) describes the ongoing legal utility of 'forensic surveying' in getting at important evidence regarding claims, rights and restitution based on a variety of forensically derived evidence.

More broadly, the current analysis can be connected to the domain encompassing political violence, evidence and international prosecutions; in that, innovations in the derivation and assemblage of evidence revealing the connection between political violence and HLP, can be added to other forms of evidence regarding political violence for use in criminal prosecutions. The Syria case lends itself to this connection by way of the vast documentation connecting those individuals giving orders to use the statutory HLP system as a weapon in various ways, to those implementing the orders, and then the fate of the HLP. Levi and Hagan write extensively on the connections be- 
tween evidence and international prosecutions regarding the war in Darfur (Levi and Hagan, 2012) and the former Yugoslavia (Hagan et. al, 2006).

While such theoretical connections have value with regard to innovations in evidence, what becomes readily apparent in this context (particularly to those targeted) is that some land and property rights systems are more easily weaponized than others. Customary tenure systems in particular are very difficult to use in this way due to their often lack of documentation, usually lineage-based membership, and non-state institutions and functioning. What this means is that during and after war, impacted societies can default back to multiple customary systems, or hybridize systems that are apart from, able to evade, or resistant to a state HLP rights system. In the case of Syria, Islamic law combined with customary practice will prove useful in this regard, especially if supported by the Civil Code--itself a result of hybridization. Any subsequent HLP mass claims process supported by the international community would do well to then build on such a foundation with robust use of innovative forms of evidence, in order to engage in an effective, legitimate HLP restitution that will be critical to any peace process, reconciliation and recovery.

\section{Bibliography}

Abdallah, T. 2011. "Syria's Land Expropriation Law: Profiting from the Public Good." Al-Akhbar, http://english.al-akhbar.com/node/666. Accessed on 7 March 2015.

Al-Zoughbi. 2004. Syrian Farming Systems Study: Farming System of the Southern Semi-arid Plains and Mountains. Damascus: National Agricultural Policy Center, Ministry of Agriculture and Agrarian Reform, Working Paper No. 11.

Anthony, A. 2014. "Jay Abdo, Syrian actor: how I changed my name from Jihad to Jay and (eventually) conquered Hollywood". The Guardian, June 15. Accessed on 4 Feb 2016: http://www.theguardian.com/film/2014/jun/15/jay-abdo-syria-film-refugee-actor

BBC. 2011. "Guide, Syria's Diverse Minorities." BBC Monitoring. http://www.bbc.com/news/ world-middle-east-16108755

Batson, D. 2007. Registering the Human Terrain: A Valuation of Cadastre. Washington, D.C: National Defense Intelligence College.

Braverman, I. 2009. Planted Flags: Trees, Land, and Law in Israel/Palestine. New York: Cambridge University Press.

Bryan, J. and D.Wood. 2015. Weaponizing Maps: Indigenous Peoples and Counterinsurgency in the Americas. New York: Guilford Press.

Caves, J 2012. Syrian Kurds and the democratic Union Party (PYD), Backgrounder, Institute for the Study of War, December 6. Institute for the Study of War, Washington DC.

Chakrani, H. 2013. "Reconstruction in Syria: All Eyes on the Prize." Al-Akhbar. http://english.al-akhbar.com/node/16041 Accessed on 13 February 2015. 
Chatty, D. 2013. Syria's Bedouin Enter the Fray: How Tribes Could Keep Syria Together. Foreign Affairs, November 13. Accessed: Feb 1, $2016<$ http://www.foreignaffairs.com/articles/140266/ dawn-chatty/syrias-bedouin-enter-the-fray>

Cohen, S. 1993. The Politics of Planting: Israeli-Palestinian Competition for Control of Land in the Jerusalem Periphery. Chicago: The University of Chicago Press.

Chulov, M. and M. Mahmood. 2013. "Syrian Sunnis Fear Assad Regime Wants to 'Ethnically Cleanse' Alawite Heartland." The Guardian Newspaper, 22 July.

Dans, H and H. Van Houtte. 2008. Post-War Restoration of Property Rights Under International Law, Vol 2, Procedural Aspects. Cambridge, UK: Cambridge University Press.

Demarest, G. 2007. Property \& Peace: Insurgency, Strategy and the Statute of Frauds. Report for the U.S. Army, Foreign Military Studies Office, Ft. Leavenworth, KS: Foreign Military Studies Office.

Debs, R.A. 2010. Islamic Law and Civil Code: The Law of Property in Egypt. New York: Colombia University Press.

Dukhan, H. 2014. Tribes and tribalism in the Syrian uprising. Syria Studies Journal, Vol 6, No 2

Habitat International Coalition - Housing and Land Rights Network (HIC-HLRN). 2015. Reconstruction: The Next Struggle in Syria. In The Land and Its People: Civil Society Voices Address the Crisis over Natural Resources in the Middle East/North Africa. Cairo: Housing and Land Rights Network, Habitat International Coalition.

Hagan, J., Levi, R., Ferrales, G. 2006. "Swaying the Hand of Justice: The Internal and External Dynamics of Regime Change at the International Criminal Tribunal for the Former Yugoslavia." Law \& Social Inquiry, 31(3) 585-616.

Herscher, A. 2008. "Warchitectural Theory." Journal of Architectural Education. 61 (3): 35-43

Hinnebusch, R. and T. Zintl, (eds.). 2015. Syria: From Reform to Revolt, Volume 1. Syracuse, NY: Syracuse University Press,.

Housing, Land and Property (HLP). 2013. Emergency Response to Housing Land and Property Issues in Syria. Nairobi: UN Habitat Briefing Note 30, January.

Isser, D., P. Van der Auweraert. 2009. Land, property, and the challenge of return for Iraq's displaced. US Institute of Peace Special Report. Washington, D.C.

Kaplan, S. 2016. "Syria's Ethnic and Religious Divisions." Fragile States. http://www.fragilestates.org/2012/02/20/syrias-ethnic-and-religious-divides/

Khraiche, D., and N. Syeed. 2015. "Jihadist Cash Lures Syrian Refugees." Bloomberg News. 7th 
April.

Kilo, M. 2011. "Syria ... The Road to Where?" Contemporary Arab Affairs, 4 (4): 431-444.

Levi, R., Hagan, J. 2012. "Lawyers, humanitarian emergencies and the politics of large numbers". In: Lawyers and the Construction of Transitional Justice. New York: Routledge

Lujala, P. and S.A. Rustad. 2012. High Value Natural Resources and Post-Conflict Peacebuilding. London: Earthscan.

Lynch, M., D. Freelon, S. Aday. 2015. Syria's Socially Mediated Civil War. Washington, DC: US Institute of Peace.

Meinzen-Dick, R., A. Mcculloch, F. Place, B. Swallow. 2002. Innovation in Natural Resource Management: The Role of Property Rights and Collective Action in Developing Countries, London: Johns Hopkins University Press.

Middle East Monitor (MEM). 2015. "Assad Regime Confiscates Opposition Properties." Middle East Monitor, February 26.

Murphy, P. 2003. Evidence, Proof, and Facts. Oxford: Oxford University Press.

*O'Bagy, E. 2013. The free Syrian army. Institute for the Study of War, March Washington, DC

Pipes, R. 1999. Property and Freedom. New York: Vintage Books.

Rae, J. 2002. "Tribes and Territory in Modern Day Syria." The Arab World Geographer 5 (2): 102112.

Reese, A. 2013. Sectarian and regional conflict in the Middle East. Middle East Security Report 13. Institute for the Study of War, Washington DC.

Sait, S. 2013. "Unexplored Dimensions: Islamic Land Systems in Afghanistan, Indonesia, Iraq, and Somalia." In Land and Post-Conflict Peacebuilding edited by Unruh, J. and R. Williams. p. 476.

Sait, S., and H. Lim. 2006. Land, Law and Islam: Property and Human Rights in the Muslim World. London: Zed Books.

Salameh, F. 2015. "The Alawites, Ethnic Cleansing, and Syria's Future". The National Interest, Accessed on March 26, 2015): http://nationalinterest.org/commentary/the-alawites-ethnic-cleansingsyrias-future-9149?page $=2$

Simons, M. 2014. "Investigators in Syria Seek Paper Trails that Could Prove War Crimes." The New York Times. October 8.

Stern, L. 2010. "Do-Gooder Terrorism." Canwest News Services, June 1. www2.canada.com/ 
ottawacitizen/columnists/story.html?id=406deb39-279c-495e-814e-e188f2373ced\&p=2.

Stigall, D. 2014. "The Civil Codes of Libya and Syria: Hybridity, Durability, and Post-Revolution Viability in the Aftermath of the Arab Spring." Emory Journal of International Law 28 (1) 1-82.

Svoboda, E., and S. Pantuliano. 2015. International and Local/Diaspora Actors in the Syria Response: A Diverging Set of Systems? Humanitarian Policy Group Working Paper, March

Syria News (SN). 2013. Government Decides on Acquisition of Land near the Damascus International Airport in order to Install Electric Poles and Towers," Syria News, 10 February, http:// www.syria-news.com/readnews.php?sy_seq $=156714$

Toal, G., C. Dahlman. 2011. Bosnia Remade: Ethnic Cleansing and Its Reversal. Oxford: Oxford University Press.

United Nations High Commission for Refugees (UNHCR). 2015. Syria Regional Refugee Response. UNHCR. http://data.unhcr.org/syrianrefugees.php Accessed on 4 Aug 2015.

Unruh, J. 2014. "Pre-Emptive and Advanced Techniques for War-Torn Land and Property Rights Reacquisition." Land Use Policy 38: 111-122.

Unruh, J., and R. Williams R (eds.) 2014 Land and Post-conflict Peacebuilding. London: Earthscan.

Unruh, J.D. and Abdul-Jalil, M.A. 2014. Constituencies of conflict and opportunity: land rights, narratives and collective action in Darfur. Political Geography 42:104-115.

Wieland, C. 2013. "Assad's Decade of Lost Chances." In The Syrian Uprising: Dynamics of an Insurgency, edited by Wieland, C., A. Almqvist, H. Nassif, (pp. 5-45). Fife: University of St. Andrews Centre for Syrian Studies.

Wilson, D. 2008. Forensic Procedures for Boundary and Title Investigation. Hoboken, New Jersey: John Wiley and Sons,

Weizman, E., and Herscher, A. 2011. Architecture, violence, evidence. Future Anterior, 8(1): 109-123.

\footnotetext{
i 'Attributes' here refers to the physical aspects of housing, land and property rights systems: registration records, lists, demarcations, maps, titles, deeds, rental and lease contracts, as well as supporting documentation.

ii The destruction comprises bombings, burnings and bulldozing at the governate, district, subdistrict, and at times village level.

iii This includes the destruction of electricity and water records that could also be used to attest to who lived where.

iv While this is not always the case for all lineage names--some names include people who affiliate with both sides of the war--nonetheless areas that one lived in or owned HLP in, can be used to distinguish, however crudely, supporters of the opposition.
} 
${ }^{\mathrm{v}}$ As noted previously approximately one-third of the urban population of 11.2 million lived in such informal settlements.

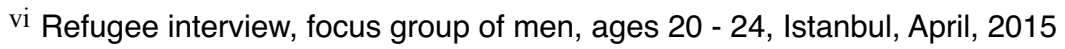

vii One estimate puts the proportion of Syria's residential areas that are unregistered at 50 percent (HIC-HLRN 2015).

viii For example, arch-news.net 2015

${ }^{i x}$ These include the construct of 'barren land' (mawat); trust or 'endowment' land and property (waqf) particularly when adapted to community welfare needs; Islamic collective tenures, and strong individual usufruct rights over state owned land (Sait 2013). 